\title{
SISTEM INFORMASI BERBASIS KOMPUTER (CBIS)
}

\author{
Oleh \\ Saliman \\ FISE UNY
}

\section{Abstrak}

Informasi adalah salah satu dari lima jenis utama sumber daya yang digunakan manajer. Pengelolaan informasi makin penting seiring dengan rumitnya kegiatan bisnis yang membutuhkan informasi yang akurat dan derni pelayanan yang memuskan pada para pelanggan. Pengelolaannya lebih menantang sejalan dengan perkembangan kemampuan komputer saat ini.

Output komputer digunakan oleh berbagai pihak untuk bahan pengambilan keputusan. Saat para manajer melakukan fungsi dan perannya, memerlukan dukungan informasi yang akurat, cepat dan tepat agar dapat melakukan tugasnya secara efektif. Hal ini bisa terwujud bila manajer memiliki keahlian dalam bidang komunikasi dan pemecahan masalah. Selanjutnya pengelolaan informasi akan merupakan sebuah sistem, yang saling tergantung sekaligus bersinergi antar berbagai komponen yang membentuk sistem tersebut. Sistem ini dikenal dengan sistem informasi. Karena digunakan untuk membantu dalam mengambil kebijakan maka disebut dengan sistem informasi manajemen.

Akibat perkembangan iembaga yang dikeloianya manajer tidak hanya mengelola sumber daya fisik saja, tetapi juga sumber daya konseptual. Sumber daya konseptual sangat abstrak sehingga sulit untuk dikelola. Cara pengelolaannya adalah dengan mengubah menjadi simbol-simbol yang memiliki value (nilai), sehingga dapat dikalkulasi. Cara pengelolaan sumber daya koseptual ini yang paling tepat adalah dengan menggunakan bantuan mesin, dalam hal ini komputer. Dengan demikian sistem informasi manajemen akan lebih etektif bila dikelola atau berbasis komputer. Sistem informasi berbasis komputer lebih dikenal sebagai (computer-based information system) atau CBIS.

Key word : CBIS, Sistem, Informasi

\section{Pendahuluan}

Setiap pimpinan suatu lembaga selalu menggunakan informasi untuk melaksanakan tugas-tugasnya, sehingga subyek dari manajemen informasi bukanlah suatu hal yang 
baru. Informasi telah ada sejak adanya manusia sampai saat ini dan masa mendatang. Kegunaan informasi juga relatif sama dari waktu ke waktu yaitu sebagai alat untuk mendukung pengambilan keputusan mulai dari keputusan individual sampai pada tingkatan keputusan seorang manajer profesional pada kalangan lembaga bisnis modern.

Daya dukung informasi terhadap pengambilan keputusan sangat berarti, sehingga cara-cara pengelolaan informasi mulai diperhatikan oleh manusia sejalan dengan perkembangan peradabanriya. Dengan demikian apa yang telah dijelaskan di atas sangat tepat bahwa subyek informasi bukanlah suatu hal yang baru, namun cara-cara mengelola informasi agar ada kemudahan dalam memperoleh informasi yang akurat dan mutakhir inilah yang selalu mengalami perkembangan sesuai dengan perkembangạn ilmu dan teknologi. Selanjutnya untuk menjawab permasalahan ini diperlukian teknologi yang mumpuni. Inovași yang sangat memungkinkan untuk mengatasi hal tersebut adalah komputer. Lembaga atau organisasi menjadi semakin sadar bahwa informasi adalah suatu sumber daya yang penting dan sangat strategis, dan komputer dapat mengelola sumber daya tersebut.

Perkembangan program-program komputer yang sengaja dirancang untuk memudahkan manajemen dalam mengelola informasi sa- ngat pesat. Aplikasi di berbagai bi-dangpun semakin luas, terutama aplikasi di bidang bisnis yang dimaklumi sebagai indikator kemajuan suatu peradaban manusia. $\mathrm{Pa}$ da dunia bisnis dikenal beberapa jenis aplikasi program komputer untuk mendukung kinerja suatu lembaga bisnis, seperti aplikasi yang berkaitan dengan penanganan transaksi akuntansi, aplikasi yang berkaitan dengan bidang manajemen sumber daya manusia, aplikasi yang berkaitan dengan bidang pengambilan keputusan, aplikasi yang berkaitan dengan bidang informasi manajemen, bahkan sampai pada kantor maya (virtual office), dan sistem berbasis pengetahuan (know-ledge-based system). Seluruh aplikasi program komputer atau lebih dikenal dengan software di bidang bisnis tersebut lebih dikenal dengan istilah sitem informasi berbasis komputer (computer-based information system), atau CBIS.

Kemampuan komputer mengelola informasi bisnis yang semakin kompleks dijelaskan oleh Reymond McLeod (2004:3) sebagai berikut:

"Informasi adalah salah satu jenis utama sumber daya yang tersedia bagi manajer. Informasi dapat dikelola seperti halnya sumber daya yang lain, dan perhatian pada topic ini bersumber dari dua pengaruh. Per-tama, bisnis telah menjadi semakin rumit, dan kedua, 
komputer telah mencapai kemampuan yang semakin baik".

Dari pendapat di atas jelaslah bahwa solusi yang dapat diambil untuk menangani dan mengelola informasi bisnis, yang setiap saat dibutuhkan untuk mendukung pengambilan keputusan pihak manajer diperlukan suatu teknologi yang mampu mendukung yaitu komputer. Tegasnya bahwa sistem informasi berbasis komputer merupakan andalan dunia bisnis. Agar dunia bisnis, kalangan pemerintahan, maupun dunia pendidikan dapat eksis maka harus menguasai informasi yang sudah berbasis komputer. Hai tersebut senada dengan pendapat Wahyudi Kumorotomo (2001:15) yang mengatakan sebagai berikut:

"... secara teoritis SIM dapat dilaksanakan tanpa bantuan alat komputer. akan tetapi sistem manajemen yang semakin kornpleks di dalam organisasi-organisasi modern, dan juga melihat kenyataan bahwa harga perangkat keras maupun perangkat lunak komputer relative semakin muran, unsure komputer tidak dapat diabaikan peranannya. Maka setiap pembahasan tentang SIM modern sekarang ini hampir dapat dipastikan akan melibatkan pembahasan tentang sistem komputer sendiri. SIM yang berbasis komputer (computer-ba-sed management information sys-tems), merupakan topic inti dalam setiap pembahasan tentang SIM".
Dengan demikian maka jelaslah bahwa sistem informasi yang paling efektif saat ini, adalah sistem informasi yang pengelolaanya menggunakan perangkat komputer, atau sistem informasi berbasis komputer.

\section{Manajemen Informasi}

Output informasi dari komputer digunakan oleh para manajer, non-manajer, serta orang-orang dan organisasi-organisasi dalam lingkungan perusahaan. Manajer berada pada semua tingkat organisasi perusahaan, dan dalam semua area bisnis Manajer melaksanakan berbagai fungsi dan peran, supaya berhasil dalam aktivitasnya manajer memerlukan keahlian dalam komunikasi dan pemecahan masalah. Manajer perlu mengerti komputer (computer literate), tetapi yang !ebih penting mereka perlu mengerti informasi (information literate).

Manajer harus mampu melihat bahwa unit yang berada di bawah kendalinya merupakan suatu sistem yang terdiri dari beberapa subsistem dan berada dalam supersistem yang lebih besar. Perusahaan atau lembaga adalah suatu sistem yang bersifat fisik, namun dikelola dengan menggunakan suatu sistem konseptual. Sistem kon-septual itu terdiri dari suatu pengolah informasi yang mengubah 
data menjadi informasi dan menggambarkan sumber daya fisik.

Penjelasan di atas dapat dipertegas dengan ilustrasi sebagai berikut: Manajer perusahaan berskala kecil dengan aset yang belum begitu besar, dan sumber daya manusia terbatas, misalnya sebuah kios, masih mampu mengelola usahanya dengan mengamati aktiva-aktiva berwujudnya seperti barang dagangan, cash register, ruangan, dan bahkan arus pelanggan. Pada saat skala operasi meningkat menjadi suatu perusahaan dengan ratusan atau ribuan pekerja, dengan operasi yang tersebar di wilayah yang luas, manajer tidak lagi dapat mengandaikan pengamatan, tetapi harus lebih mengandalkan informasi. Manajer memanfaatkan banyak laporan atau informasi untuk memahami atau mengetahui kondisi fisik perusahaan. Sehingga dapat dibayangkan betapa mudahnya seorang direktur memahami seluruh kondisi perusahaan dalam sesaat dengan memanfaatkan informasi, sekaligus mengandalkan informasi tersebut untuk pengambilan keputusan.

Dengan demikian para manajer menyadari sepenuhnya bahwa informasi merupakan suber daya yang sangai berharga, sehingga perlu dikelola sebaik-baiknya, hal ini senada dengan pendapat Wahyudi Kumorotomo ((2001:2) yang menjelaskan bahwa semakin banyak organisasi atau perusahaan yang mencurahkan perhatian utamanya pada penciptaan informasi yang bermanfaat bagi manajemen, namun yang lebih penting lagi adalah bahwa hanya perusahaan atau organisasi yang mampu mencari dan mendapatkan informasi secara efektif yang akan berhasil. Lebih jauh Reymond McLeod (2004:3) menjelaskan tentang pentingnya sumber daya informasi, dengan memasukkan informasi ke dalam lima jenis utama sumber daya, yaitu: manusia, material, mesin (termasuk fasilitas dan energi), uang, dan informasi (termasuk data). Tugas manajer adalah mengelola kelima sumber daya tersebut agar dapat digunakan dengan cara yang paling efektif. Empat jenis sumber daya yang pertama memiliki wujud (kasat mata), sehingga secara fisik dapat disentuh, dikelola dan dimanfaatkan secara langsung. Sumber daya tersebut dikenai dengan istilah sumber daya fisik, sedangkan sumber daya yang ke lima yaitu informasi, hanya memiliki nilai dari apa yang diwakilinya, bukan dari bentuk atau wujudnya. Sumber daya informasi disebut juga dengan sumber daya koinseptual. Para manajer dituntut agar dapat menggunakan sumber daya konseptual untuk mengelola sumber daya fisik.

Terkait dengan pendapat di atas Wahyudi Kumorotomo (2001:9) menjelaskan bahwa setiap unsur pembentuk organisasi adalah penting dan harus mendapat 
perhatian yang utuh supaya manajer dapat bertindak lebih efekti. Kemudian yang dimaksud dengan unsur atau komponen pem-bentuk organisasi adalah bukan ha-nya bagian-bagian yang tampak se-cara fisik, tetapi juga hal-hal yang bersifat abstrak atau konseptual.

Sumber daya diperoleh dan disusun agar siap digunakan pada saat diperlukan. Pada proses penyusunan sumber daya mengharuskan kegiatan pengubahan bahan mentah menjadi suatu bentuk yang lebih siap digunakan, menjadi lebih halus, tepat ukuran, akurat, pasti, dan sebagainya.

Proses pengolahan atau penyusunan sumber daya menjadi lebih baik tersebut, memerlukan biaya mahal, sehingga setelah sumber daya tersebut disusun seorang manajer dituntut untuk memaksimalkan penggunaan sumber daya dalam kegiatan manajemennya. Selanjutnya manajer harus meminimalkan biaya dan waktu yang terbuang untuk perbaikan sumber daya dengan cara menjaga berfungsinya sumber daya secara kontinyu pada titik efisiensi puncak. Manajer baru melakukan penggantian sumber daya teisebut pada saat kritis, sebelum sumber daya tersebut menjadi tidak efisien atau usang.

Seperti telah dijelaskan sebelumnya bahwa sumber daya terdiri dari sumber daya fisik dan sumber daya konseptual. Manajer harus mampu mengelola kedua sumber daya tersebut. Mengelola sumber daya konseptual dalam hal ini informasi tidak semudah mengelola sumber daya fisik, karena obyek yang dikelola hanya merupakan representasi dari suatu benda berujud atau bahkan hanya sebuah fenomena yang hanya dapat dirasakan. didengar atau dicium baunya. Dengan demikian dibutuhkan personal yang memahami value added dari sebuah sumber daya konseptual, agar model dan cara pengelolaannya tepat. Manajer harus memahami bahwa lahirnya sebuah informasi melalui tahapan yang cukup rumit, sehingga mampu memfasilitasi personal yang bertugas mengelola sumber daya konseptual.

Fasilitas yang disediakan harus mencakup semua proses pengelolaan informasi mulai dari pengumpulan data mentah, sampai pada kegiatan proses data menjadi sebuah informasi yang berguna. Informasi tersebut selanjutnva akan didistribusikan kepada piilak-pihak dalam organisasi yang layak menerima, dalam bentuk yang tepat, saat yang tepat sehingga dapat dimanfaatkan secara optimal. Akhirnya manajer akan membuang atau memusnahkan informasi yang tidak berguna untuk diganti dengan informasi yang lebih mutakhir dan akurat. Kegiatan tersebut harus dilakukan oleh personal pengelola sumber daya konseptual dengan dukungan fasilitas yang memadai. Seluruh aktivitas tersebut mulai dari 
memperolah informasi, menggunakannya seefektif mungkin, dan membuangnya pada saat tidak dibutuhkan lagi, dengan dukungan fasilitas yang memadai oleh Reymond McLeod (2004:4) disebut dengan istilah manajemen informasi.

\section{Perkembangan Manajemen Infor- masi}

Peningkatan penggunaan sistem informasi pada akhir-akhir ini, tidak terlepas dari perhatian manajemen dalam perusahaan terhadap betapa pentingnya manajemen informasi. Para manajer memberikan perhatian yang semakin besar pada manajemen informasi selama beberapa tahun terakhir ini, karena dua alasan utama. Pertama, kegiatan bisnis telah menjadi semakin rumit. Kedua, komputer telah mencapai kemampuan yang semakin baik. Secara lebih rinci dapat dijelaskan sebagai berikut:

\section{Kegiatan Bisnis Semakin Rumit}

Bisnis memang selalu rumit, tetapi sekarang ini lebih rumit dibandingkan sebelumnya. Semua perusahaan terkena pengaruh ekonomi internasional dan bersaing dalam pasar internasional, teknologi bisnis menjadi semakin rumit, batas waktu untuk bertindak semakin singkat dan terdapat pula kendala-kendala sosiai. Setiap pengaruh ini memberi kontribusi pada kerumitan bisnis.

Mengenai pengaruh ekonomi internasional dapat dimaklumi karena perusahaan-perusahaan

besar maupun kecil semua terkena pengaruh ekonomi yang dapat bersumber dari bagian dunia manapun. Pengaruh tersebut dapat terlihat pada nilai relative mata uang tiap negara. Pembeli melakukan pembelian di Negara-negara yang mata uangnya miemiliki nilai paling besar. Sebagai contoh, saat Meksiko mendevaluasikan peso pada akhir 1980-an, banyak turis Amerika Serikat yang memutuskan untuk berlibur di Meksiko daripada di tempat lain, seperti Hawaii.

Sedangkan persaingan dunia dapat dijelaskan bahwa perusahaan-perusahaan tidak lagi bersaing dalam wilayah geografisnya sendiri. Sebaliknya persaingan terjadi pada skala dunia. Dampak dari persaingan ini dapat terlihat pada impor dari luar negeri. Sebagai contoh keputusan General Motors pada awal tahun 1990-an untuk menutup banyak pabriknya menunjukkan bahwa industri raksasa pun tidak terhindar dari dampak persaingan, yang dapat berasal dari bagian dunia manapun.

Sementara itu kerumitan ieknologi yang meningkat dapat dilihat setiap saat bahwa berbagai teknologi yang diterapkan dalam dunia bisnis selalu mengalami perubahan yang sangat pesat. Bebarapa kemudahan pelayanan teknologi memanjakan manusia seperti bar code scanners di pasar swalayan, 
sistem pemesanan penerbangan yang berbasis komputer, automated teller machine, dan closed circuit television di gedung-gedung parkir. Juga terdapat banyak teknologi di belakang layar, yang tidak terlihat misalnya robot-robot pabrik, serta peralatan otomatis untuk penanganan dan penyimpanan barang dagangan. Perusahaan-perusahaan melakukan investasi pada teknologi ini supaya mereka dapat melaksanakan operasi yang diperlu-kan secara lebih efektif.

Batas waktu juga semakin singkat, dapat diketahui bahwa semua tahap operasi bisnis sekarang ini dilaksanakan secara lebih cepat daripada sebelumnya. Para wiraniaga melakukan pemasaran melalui telepon (telemarketing) untuk menghubungi pelanggan mereka dalam beberapa detik, perintah penjualan dikirim secara elektronik dari satu komputer ke komputer yang lain, dan pabrik membuat jadwal pengiriman material agar tiba tepat pada waktunya (just in time).

Namun demikian kendala-kendala sosial juga tetap ada, di mana tidak semua tekanan mendukung produksi, sebagian malah mendorong non-produksi. Hal ini nyata pada produk dan jasa yang tidak diinginkan masyarakat. Keputusan-keputusan bisnis harus didasarkan pada faktorfaktor ekonomis, tetapi keuntungan dan biaya sosial harus juga dipertimbangkan. Perluasan pabrik, produk baru, tempat penjualan baru, dan tindakan-tindakan serupa semuanya harus dipertimbangkan dampaknya terhadap lingkungan.

\section{Kemampuan Komputer yang Semakin Baik}

Dalam hal ukuran dan kecepatannya, komputer-komputer tahun 1950-an dan 1960-an tampak seperti dinosaurus dari Jurassic Park. Komputer-komputer ini ditempatkan dalam "ruangan besar" dan hanya boleh disentuh oleh para spesialis komputer perusahaan. $\mathrm{Pa}$ ra pemakai tidak pernah berhubungan langsung dengan perangkat keras, tetapi pengaturan seperti ini di rasa cocok oleh para pemakai. Umumnya, pemakai tidak tahu cara menggunakan komputer dan takut untuk belajar.

Para pemakai komputer sekarang justru sebaliknya, sangat mungkin memiliki terminal keyboard atau komputer mikro di ruangan mereka. Banyak komputer mikro dihubungkan dengan komputer-komputer lain dalam suatu jaringan. Bukan hanya komputer yang tersedia, para pemakai pun tahu cara menggunakannya. Para pemakai sekarang tidak miemiandang komputer sebagai sesuatu yang istimewa tetapi sebagai bagian peralatan kantor yang dibutuhkan, seperti halnya meja, telepon atau mesin fotokopi. 


\section{Pemakai Informasi}

Awalnya pemakai output komputer adalah pegawai administrasi di bagian akutansi, yang komputernya melaksanakan aplikasi seperti pembayaran gaji, pengelolaan persediaan, dan penagihan. Sebagian informasi juga di sediakan bagi para menejer, tetapi hanya sebagai produk sampingan dari aplikasi akuntansi

Gagasan untuk menggunakan komputer sebagai suatu sistem informasi manajemen (SIM), merupakan suatu terobosan besar, karena menyadari bahwa para manajer memerlukan informasi untuk pemecahan masalah. Saat perusahaan-perusahaan menjangkau konsep SIM, mulai dikembangkan berbagai aplikasi yang secara khusus diarahkan untuk mendukung manajemen. Kroenke dalam Abdul Kadir (2003:5) menjelaskan bahwa sistem informasi memberikan nilai tambah terhadap proses produksi, kualitas, manajemen, pengambilan keputusan, dan pemecahan masalah serta keunggulan kompetitif yang tentu saja sangat ber.yuna bagi kegiatan bisnis. Sebenarnya bukan hanya manajer yang memperoieh manfaat dari SIlvi, para pegawai nonmanajer juga menggunakan produk SIM:, bahkan yang berada di luar perusahaan, seperti para pelanggan yang menerima faktur dan laporan, para pemegang saham menerima cek dividen, dan pemerintah menerima laporan pajak. Dengan demikian dapat dikatakan bahwa para pema-kai
SIM meliputi: manajer, non-manajer, orang atau organisasi di luar perusahaan.

\section{Fungsi dan Peran Manajer}

Pada tahun 1914, seorang ahli teori manajemen berkebangsaan Perancis, Henry Fayol, menyatakan bahwa manajer melaksanakan lima fungsi-fungsi manajemen yang utama. Pertama, manajer merencanakan (plan) apa yang akan mereka lakukan. Kemudian, menyusun staf (staff) organisasi mereka dengan sumber daya yang diperlukan. Dengan sumber daya yang ada, mereka mengarahkan (direct) untuk melaksanakan rencana. Akhirnya mereka mengendalikan (control) sumber daya, menjaganya agar tetap beroperasi secara optimal. Semua manajer, apapun tingkatannya melaksanakan fungsi-fungsi tersebut, walaupun mungkin dengan penekanan yang berlainan.

Sementara itu Henry Mintzberg, professor pada McGill University Kanada, menganggap bahwa fungsi-fungsi Fayol tidak memberikan gambaran yang menyeluruh. la mengembangkan kerangka kerja yang lebih yang harus dimainkan oleh manajer, meliputi aktivitas antar-pribadi (interpersonal), informasi (informational) dan keputusan (decisional).

Sistem informasi manajemen yang baik, dirancang berdasarkan 
fungsi-fungsi dan peran-peran manajerial tersebut. Di samping itu agar SIM yang dirancang oleh suatu lembaga benar-benar fungsional, maka harus dikembangkan dengan memperhatikan keahlian yang harus dimiliki oleh seorang manajer Reymond McLeod (2004:7-8). Keahlian tersebut meliputi keahlian dalam berkomunikasi dan keahlian dalam memecahkan masalah. Keahlian tersebut akan segera terbentuk apabila SIM yang dikembangkan benar-benar fungsional.

Keahlian manajer dalam berkomunikasi meliputi kegiatan menerima dan mengirimkan informasi dalam bentuk lisan atau tertulis. Komunikasi tertulis meliputi laporan, surat, memo, surat elektronik dan terbitan berkala. Komunikasi lisan terjadi saat rapat, saat menggunakan telepon atau voice mail, saat meninjau fasilitas, dan selama acara makan, bisnis serta berbagai kegiatan sosial. Tiap manajer memiliki pilihan medianya sendiri. Seorang manajer mungkin lebih menyukai percakapan telepon daripada surat elektronik, sementara yang lain mungkin kebalikannya. Para manajer menyusun suatu perpaduan media komunikasi yang sesuai dengan gaya manajemen mereka.

Keahlian manajer dalam memecahkan masalah (problem solving) dapat didefinisikan sebagai semua kegiatan yang mengarah pada solusi suatu permasalahan. Masalah biasanya dianggap sebagai sesuatu yang selalu buruk, karena sangat sedikit yang menganggap masalah sebagai sesuatu untuk meraih kesempatan. Hasil dari aktivitas pemecahan masalah adalah solusi. Selama proses pemecahan masalah, manajer terlibat dalam pengambilan keputusan (decision making), yaitu tindakan memilih dari berbagai alternatif tindakan. Keputusan adalah suatu tindakan tertentu yang telah dipilih.

\section{Manajer dan Sistem}

Ahli-ahli manajemen sering mengatakan bahwa jika seorang manajer memandang organisasinya sebagai suatu sistem, hal itu akan menjadikan pemecahan masalah lebih mudah dan lebih efektif. Sistem adalah sekelompok elemenelemen yang terintegrasi dengan maksud yang sama untuk mencapai tujuan. Suatu organisasi seperti perusahaan atau suatu area bisnis cocok dengan definisi ini. Organisasi terdiri dari sejumlah sumber daya, di mana sumber daya tersebut bekerja menuju tujuan tertentu yang telah ditentukan oleh pemilik atau manajemen.

Di samping konsep sistem, ada lagi konsep supersistem dan subsistem. Jika suatu sistem adalah bagian dari sistem yang lebih besar, sistem yang lebih besar itu adalah supersistem. Contohnya, pemerintahan kota adalah suatu sistem, tetapi ia juga merupakan bagian dari sistem yang lebih besar 
yaitu pemerintahan propinsi. Pemerintahan propinsi adalah supersistem dari pemerintahan kota dan juga merupakan subsistem dari pemerintahan nasional.

Dalam dunia bisnis, sistem perusahaan berada dalam satu atau lebih sistem lingkungan yang lebih besar atau supersistem. Jika perusahaan itu suatu bank, misalnya, perusahaan tersebut merupakan bagian dari masyarakat keuangan. Perusahaan tersebut juga merupakan bagian dari masyarakat bisnis, masyarakat setempat, dan masyarakat global.

Sistem perusahaan juga mencakup sistem-sisiem yang lebih kecil atau subsistem. Subsistem dari bank mungkin barupa departemen-departemen seperti tabungan, rekening koran dan pinjaman angsuran. Walaupun tiap subsistem ini memiliki tujuannya masing-masing, tujuan-tujuan bawahan ini mendukung dan memberi kontribusi pada tujuan keseluruhan perusahaan. Antara supersistem, sistem dan subsistem harus terjalin dalam satu kesatuan yang bersinergi. Ketiganya harus diikat dalam sebuah sistem informasi manajemen. Dengan demikian sistern informasi yang menghasilkan informasi dongan akurasi dan presisi tinggi menjadi sebuah keharusan, agar ketiga sistem tersebut dapat berjalan seiring dan sejalan dalam mencapai tujuan.

Manajer pada tingkat supersistem disebut manajer puncak (top manger), manajer pada tingkat sis- tem disebut manajer menengah (middle manager), dan manajer pada tingkat subsistem disebut manajer rendah (lower manager). Ketiga tingkat manajer tersebut dapat bekerjasama dengan baik apabila didukung oleh sistem informasi yang handal, yang mampu menghasilkan informasi yang memiliki akurasi dan presisi tinggi, sehingga keputusan yang diambil pada tingkat manajer puncak tidak akan bertentangan dengan keputusan pada tingkat manajer rendah, atau sebalinya. Hal ini hanya mungkin terjadi apabila sistem informasi yang digunakan sudah berbasis komputer (CBIS), dan saling berhubungan satu sama lain. Sejalan dengan pendapat di atas mengenai kualitas informasi agar dapat digunakan untuk mengambil keputusan secara tepat, Abdul Kadir (2003:46) menjelas'ran bahwa informasi yang berkualitas adalah informasi yang baik, yang memiliki karakteristik : relevansi, ketepatan waktu, dan keakurasian.

\section{Macam dan Nilai CBIS}

Manajer membuat keputusan untuk memecahkan masalah, dan informasi digunakan dalam membuat keputusan. Informasi disajikan daiam bentuk lisan maupun tertulis oleh suatu pengolah informasi. Porsi komputer dalam mengolah informasi terdiri dari berbagai aplikasi berbasis komputer, seperti SIA, SIM, DSS, kantor virtual dan 
sistem berbasis pengetahuan, Reymond McLeod (2004:14).

Istilah yang mencakup semua aplikasi berbasis komputer adalah sistem informasi berbasis komputer (computer based information system), atau CBIS, untuk menggambarkan lima subsistem yang menggunakan komputer. Semua subsistem CBIS menyediakan informasi untuk pemecahan masalah.

Tanpa memandang apakah spesialis informasi atau pemakai yang mengembangkan aplikasi, CBIS harus dinilai dengan cara yang sama seperti investasi besar lain dalam perusahaan. Sebenarnya sangat sulit mengukur nilai CBIS, ada perusahaan yang mencoba menimbang nilai komputer berdasarkan biaya tenaga administrasi (clerical cost) yang digantikan. Sebenarnya hal ini tidaklah tepat, karena setelah ada CBIS hanya sedikit pegawai administrasi yang kehilangan pekerjaanya. Namun manfaat yang besar diperoleh perusahaan setelah ada CBIS, yaitu mampu mencapai peningkatan efisiensi dan efektivitas, bahkan mampu mengurangi investasi.

Sebagi bukti bahwa CBIS itu lebih efisier, dari pendahulunya (sistem manual), dijelaskan oleh Reymond McLeod (2004:19) bahwa salah satu aplikasi komputer pertama adalah pengendaiian persediaan dan perusahaan umumnya dapat mengurangi investasi persediaan mereka dengan mengkomputerisasi catatan persediaan.
Karena sukarnya mengukur nilai CBIS, perusahaan-perusahaan sangat berhati-hati dalam membuat keputusan untuk menerapkan sistem seperti itu. Banyak waktu manajer dan staf yang dihabiskan untuk mengevaluasi dampak sistem itu pada organisasi. Menimbang-nilai CBIS, dengan menggunakan gabungan ukuran-ukuran kuantitatif dan subyektif, adalah langkah kunci dalam mencapai sumber daya yang berharga ini.

Dalam beberapa hal, nilai CBIS juga dapat dipertimbangkan dari siklus CBIS. Tiap subsistem CBIS menyerupai suatu organisme hidup yaitu : lahir, bertumbuh, menjadi matang, berfungsi dan akhirnya mati. Proses evolusi ini disebut siklus hidup sistem (system life cycle SLC), dan terdiri dari tahap-tahap berikut: (1) Perencanaan; (2) Analisis; (3) Rancangan; (4) Penerapan; dan (5) Penggunaan.

Siklus hidup suatu sistem berbasis komputer mungkin hanya berlangsung beberapa bulan, atau mungkin berlangsung beberapa tahun, sehingga dapat dikatakan bahwa CBIS mempunyai biaya yang tinggi. Cepat atau lambat, sifat dinamis kebutuhan informasi akan melampaui kemampuan sistem informasi, sehingga sistem itu harus diperbarui. Tahap-tahap siklus hidup sistem membentuk suatu pola lingkaran. Saat suatu sistem berakhir masa kegunaannya dan harus 
diganti, suatu siklus hidup baru dimulai, diawali dengan tahap perencanaan.

Walau banyak orang mungkin menyumbangkan keahlian khusus mereka untuk pengembangan sistem berbasis komputer, pemakailah yang bertanggung jawab atas siklus hidup sistem. Sesuai dengan penekanan pada manajer sebagai pemakai, tanggung jawab untuk mengelola CBIS ditugaskan pada manajer. Manajer ini adalah manajer dari unit organisasi tempat diaplikasikannya komputer dan dapat ditempatkan di mana saja di dalam perusahaan.

Seiring berkemibangnya CBIS, manajer merencanakan siklus hidup dan mengatur para spesialis informasi yang terlibat. Setelah penerapan, manajer mengendalikan CBIS untuk memastikan bahwa sistem tersebut terus menyediakan dukungan yang diharapkan. Saat manajer memilih untuk memanfaatkan dukungan para spesialis informasi, kedua pihak bekerja sama untuk mengidentifikasi dan mendefinisikan masalah, mengidentifikasi dan mengevaluasi solusi alternatif, memilih solusi terbaik, merakit perangkat keras dan perangkat lunak yang sesuai, menciptakan database. dan menjaga kemutakhiran sistem. Semua kegiatan tersebut akan dapat dilakukan dalam waktu relative singkat apaiila perusahaan telah menggunakan sistem informasi berbasis komputer.

\section{Penutup}

Kemajuan jaman ditandai dengan kemajuan di bidang ilmu pengetahuan dan teknologi, termasuk di dalamnya kemajuan di bidang teknologi informasi. Suatu lembaga selalu membutuhkan informasi yang terkini dan memiliki akurasi yang cukup tinggi untuk mendukung pengambilan kebijakan-kebijakannya, apabila ingin meraih keunggulan kompetitif. Informasi menjadi sangat penting bagi siapapun yang ingin menguasai keunggulan. Informasi adalah salah satu dari lima jenis utama sumber daya yang dapat dipakai oleh manajer. Semua sumber daya termasuk informasi dapat dikelola. Pengelolaan informasi semakin penting seiring dengan rumitnya kegiatan bisnis yang setiap saat membutuhkan informasi yang akurat dan demi pelayanan yang memuskan pada para pelanggan. Pengelolaan informasi juga lebih menantang sejalan dengan perkembangan kemampuan komputer saat ini.

Produk komputer digunakan oleh berbagai pihak untuk bahan pengambilan keputusan, terutama seorang manajer dalam suatu perusahaan. Saat para manajer melakukan fungsi dan perannya, memerlukan dukungan informasi yang akurat, cepat dan tepat agar dapat melakukan tugasnya secara efektif dan efisien. Hal ini akan terwujud apa-bila manajer memiliki keahlian 
dalam bidang komunikasi dan pemecahan masalah dengan pengetahuan tentang komputer dan informasi. Selanjutnya pengelolaan informasi akan merupakan sebuah sistem, yang saling tergantung sekaligus bersinergi antar berbagai komponen yang membentuk sistem tersebut. Sistem ini dikenal dengan sistem informasi. Karena digunakan untuk membantu manajer dalam mengambil kebijakan maka disebut dengan sistem informasi manajemen.

Akibat perkembangan lembaga yang dikelolanya manajer tidak hanya mengelola sumber daya fisik saja, tetapi juga sumber daya konseptual. Sumber daya konseptual sangat abstrak sehingga sulit untuk dikelola. Cara pengelolaannya adalah dengan mengubah menjadi simbol-simbol yang memiliki value (nilai), sehingga dapat dikalkulasi. Cara pengelolaan sumber daya koseptual ini yang paling tepat adalah dongan menggunakan bantuan mesiit, dalam hal ini komputer. Dengan demikian sistem informasi manajemen akan lebih efektif apabila dikelola atau berbasis $\mathrm{kcm}$ puter. Sistem informasi berbasis komputer tersebut lebih dikenal sebagai (computer-based information system) atau CBIS.

\section{Daftar Pustaka}

Abdul Kadir, 2003, Pengenalan Sistem Informasi, Yogyakarta : Andi Offset.

Brown, Carol V., dan Bostrom, Robert P. (Spring:1994). "Organization Designs for the Management of End-User Computing: Reexamining the Contingencies." Journal of Management Information System.

Cale, Edward G., Jr., dan Kanter, Jerry. (Number 1: 1998). "Aligning Information Systems and Business Strategy: A Case Study". Journal of Information Technology Management.

Mirani, Rajesh, dan King, William R. 1994. "The Development of a Measure for End - User Computing Support," Decision Sciences.

Moekijat, 1988, Sistem Informasi Manajemen, Bandung : CV Remaja Karya.

Raymond McLeod, Jr. dan George Schell. 2004. Sistem Informasi Manajemeri (terjemahan). Jakarta: PT Indeks

Siagian, S.P, 1984, Sistem Informasi untuk Pengambilan Keputusan, Jakarta: Gunung Agung.

Wahyudi

Kumorotomo dan

Subando Agus Martono, 2001, Sistem Informasi Manajemen, Yogya-karta : 
Gadjah Mada University Press. Yoder, D. 1964. Handbook of Personnel Management and Labour Relation, New York: Long Man.

Yogiyantoro HM, 1990, Analisis dan Desain Sistem Informasi: Pendekatan Terstruktur, Yogyakarta : Andi Offset.

2000, Sistem Informasi Berbasis Komputer : Konsep Dasar dan Komponen, Edisi Ketiga, Yogyakarta : BPFE
Yoon, Younghoc. (Spring : 1999). "Discovering Knowledge in Corporate Databases." Information Management.

Systems

\section{Biodata Penulis}

Saliman, lahir di Kutasari, Purbalingga, 3 Agustus 1966 adalah Lektor Kepala pada Program Studi Pendidikan Administrasi Perkantoran, Fakultas IImu Sosial dan Ekonomi, Yogyakarta.
Negeri
Universitas 